\title{
Growth Parameters and Yield Evaluation of Tropical and Temperate Sweetpotato Genotypes Under Acid Soil Conditions
}

\author{
S.R. Paul ${ }^{1}$, A.F.M.S. Islam ${ }^{1}$, M.A. Maleque ${ }^{2}$, R. Tabassum ${ }^{1}$ and F.I. Monshi ${ }^{3}$
}

\begin{abstract}
Sweetpotato (Ipomoea batatas L. Lam) is an important tuber crop with a wide range of eco-physiological adaptability. The analysis of diversified crops could be an approach to explore sweetpotato productivity under acid soil conditions. To observe the yield performance of nine sweetpotato genotypes with temperate origin (Japanese) and tropical origin (Bangladeshi), the experiment was conducted in the acidic soil and tropical environment of Sylhet, Bangladesh. The experiment was laid out in Randomised Complete Block Design with three replications. For the growth studies data were recorded at 30 days after planting (DAP) and morphological and yield parameters were recorded at final harvest. Results showed that the morphological
\end{abstract}

${ }^{1}$ Department of Crop Botany and Tea Production Technology, Faculty of Agriculture, Sylhet Agricultural University, Bangladesh.

2Department of Entomology, Faculty of Agriculture, Sylhet Agricultural University, Bangladesh.

${ }^{3}$ Department of Genetics and Plant Breeding, Faculty of Agriculture, Sylhet Agricultural University, Bangladesh.

*monshifi.gpb@sau.ac.bd

http://orcid.org/0000-0003-3198-0219

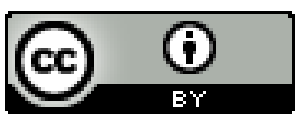

This article is published under the terms of the Creative Commons Attribution 4.0 International License which permits unrestricted use, distribution and reproduction in any medium provided the original author and source are credited. parameters and yield contributing characteristics varied widely among the genotypes. The highest number of branches per plant (6.03), dry weight of storage root per plant (323.8 g), total fresh weight per plant (1132 g), total dry weight per plant (362.4 g) and yield of storage roots per hectare $(27.05 t)$ were found in Local 1 whereas the lowest length of storage root per plant $(8.70 \mathrm{~cm})$, diameter of storage root per plant $(9.37 \mathrm{~cm})$, storage root number per plant (3.17), the storage root dry weight per plant (104.5 g), total fresh weight per plant (550.3 g) and dry weight per plant (152.9 g) were recorded in JSP 1. Among the sweetpotato genotypes, local genotypes were performed better than those of exotic genotypes in acidic soils. The genotypes Local 1 was found suitable with better growth and yield performance in acidic soils.

Keywords: Acid soil, Sweetpotato, Temperate, Tropical, Yield performance

\section{INTRODUCTION}

Sweetpotato (Ipomoea batatas L.), one of the most important tuber crops, is cultivated in almost every area of Bangladesh. As the farmer's perception, this crop has high economic value to fulfil the requirement of food demand of the country which is recognized as the fourth important crop after rice, 
wheat and potato (Delowar and Hakim, 2014). Its popularity has increased because it can easily be grown in fallow lands, riverbanks, valley areas and homestead areas. Even the plant can survive in adverse environmental and edaphic conditions and it shows flexibility both in planting and harvesting times (Namanda, 2012; Motsa et al., 2015). Moreover, sweetpotato has high nutritional value having a vital source of carbohydrates, vitamins, and minerals (Vargas et al., 2017), in addition, the orange-fleshed cultivars are rich in beta-carotene which has provitamin $\mathrm{A}$ and antioxidant activity (Laurie and Heerden, 2012). Therefore, considering its significant importance, expanding the cultivation area to increase production is a crucial need to ensure food security in Bangladesh.

Although sweetpotato is originated from Central America presently it is widely grown in the tropical and subtropical region, and even in some parts of temperate countries (Chandrasekara and Joshephkumar, 2016). When accounting for the global sweetpotato cultivation region, Asia is ranked as the world's largest about $78.4 \%$, followed by Africa $(17.1 \%)$, North America (1.8\%), South
America (1.3\%) and Oceania (1.2\%) (FAOSTAT, 2019). The average yield of sweet potato is insufficient in Bangladesh in comparison with other tropical and subtropical countries (Verma et al., 1994) as cultivating the local and poor quality sweet potato varieties. Therefore, it is an urgent need to develop high-yielding varieties through evaluating the existing varieties as well as the introduction of exotic high-yielding varieties.

Higher production of sweetpotatoes utilizing vast area of Bangladesh can accomplish the food demand for an ever-increasing population. Because rural people in most of the developing countries are directly reliable in the production of staple crops. Moreover, traditionally, farmers are cultivating sweetpotato after T. Aman rice (the major rice crop growing from mid-June to November in Bangladesh) or in fellow land with no or less care and input (Nazrul, 2018). That's why its cultivation could not reach its maximum yield potential, resulting in lower yield production. The morphological and yield contributing characteristics like leaf area, leaf production, leaf photosynthesis, tuber formation and development, total dry matter production, and tuber yield 
depend on genetic and environmental factors (Hayati et al., 2020). For improving sweet potato varieties, the analysis of genotypes at the genetic level with agro-morphological traits (Mahmud et al., 2021; Rosero et al., 2020) can provide more information that will be helpful for the plant breeders.

The soil of our experimental area, Sylhet is slightly acidic ( $\mathrm{pH} 4.80$ ) in nature although Laurie and Niederwieser (2004) suggested the soil $\mathrm{pH}$ between 5.6 and 6.6 for higher sweetpotato production. But the rapid growth of the vine and root traits can easily cover the soil which enhances the reduction of soil acidity (Essilfie $e t$ al., 2015) and combats with the soil erosion in hilly areas. In Bangladesh, there are some varieties of sweetpotato developed by different research organizations like the Bangladesh Agricultural Research Institute (BARI) for commercial cultivation. But till now, a little initiative was taken to research sweetpotato for the acidic soil condition in the Sylhet region (Hossain et al., 2018; Nazrul, 2018; Rahman et al., 2015), so far no cultivar was developed. Keeping this idea in mind, nine genotypes of sweetpotato (exotic and local) were collected to evaluate their growth and yield performances in the acidic soils. In the present study, attempts have been taken to evaluate the morphophysiological characteristics and highyielding sweetpotato genotypes in the acid soil.

\section{MATERIALS AND METHODS}

\section{Experimental Materials and Cultivation}

The experiment was conducted at the research farm of Sylhet Agricultural University, Sylhet (latitude 24 ${ }^{\circ} 54^{\prime}$ 34.07" N and longitude 91'54' 5.43" E). The soil of the experimental fields is sandy loam type characterized by acidic in nature. The soil $\mathrm{pH}$ of the research field was 4.80. Monthly rainfall, air temperature, sunshine hours and humidity at the experimental site were collected from the Meteorological Station.

During land preparation, the total amount of cow dung (10 ton ha-1) was applied in the field. Except for urea, other fertilizer TSP (214 kg ha-1), MoP (210 kg ha-1), Gypsum (91.4 kg ha-1), Boric acid $\left(5.0 \mathrm{~kg} \mathrm{ha}^{-1}\right)$ and Magnesium sulfate $(93.0 \mathrm{~kg})$ were applied at the time of final land preparation. Two days after the application of TSP, Zinc sulfate $\left(9.0 \mathrm{~kg} \mathrm{ha}^{-1}\right)$ was applied in the 
field. Urea (220 $\mathrm{kg} \mathrm{ha-1})$ was sidedressed in two equal instalments after 25 and 55 days of vine planting.

The vine cuttings of four temperate and five tropical sweetpotato cultivars (Table 1) were used in the study. The vine cuttings ranging from 40 to $50 \mathrm{~cm}$ long with six to seven nodes were grown. The nine genotypes were laid out in a randomized complete block design (RCBD) with three replications. The experimental area was divided into three equal blocks which were sub-divided into 9 plots. The vines of each genotype were planted in the lines with a spacing of $0.40 \mathrm{~m}$ and 0.30 $\mathrm{m}$ from row to row and plant to plant, respectively.

\section{Estimation of Growth, Yield and Tuber Quality}

Six plants from each plot were sampled for data collection on morphological growth parameters. Plants were evaluated on mature leaf blade and vein colour, mature leaf shape, petiole pigmentation, length of the main vines. Storage roots were evaluated on shape, skin colour and flesh colour by visual observation. In the initial growth stage, the vine length was measured at 15 days interval from 45 DAP to 90 DAP and later measured at 30 days interval up to 150 DAP. Initially, the number of branches per plant was counted at 15 days interval from 45 to 75 DAP which was then measured separately at 150 DAP. The dry weight of each sample

Table 1. Name, origin and classification of the sweetpotato cultivars.

\begin{tabular}{|l|l|c|}
\hline \multicolumn{1}{|c|}{ Origin } & \multicolumn{1}{|c|}{ Genotype/ Line } & Region \\
\hline Japanese & JSP 1 (Japanese Sweetpotato-1) & Temperate \\
& JSP 2 (Japanese Sweetpotato-2) & \\
& JSP 3 (Japanese Sweetpotato-3) & \\
& JSP 4 (Japanese Sweetpotato-4) & \\
\hline Bangladeshi & BARI SP 7 & Tropical \\
& BARI SP 9 & \\
& Local 1 & \\
& Local 2 & \\
& Local 3 & \\
\hline
\end{tabular}


was analysed by oven drying at $80^{\circ} \mathrm{C}$ for 72 hours until their weight become constant. The number and length of storage roots were measured and averaged. The diameter of storage roots was measured by a slide calliper at three points (tip, middle and base) and averaged. Leaf area per leaf was measured at different days of planting at 75, 90 and 120 DAP. Leaf area index (LAI) was calculated according to a previous report (Watson, 1947). Dry weights of above-ground biomass like leaf, vine and different root biomass were measured at 120 DAP. At the final harvest, storage roots were weighed and yield was calculated per unit area and then converted into tons per hectare.

\section{Leaf Chlorophyll \\ Determination}

Content

From the top of the canopy, fully expanded sweetpotato leaves were collected at $30 \mathrm{DAP}, 60 \mathrm{DAP}$ and 90 DAP. About $250 \mathrm{mg}$ of leaf materials were ground finely by a motor pestle with $25 \mathrm{ml}$ cold $80 \%$ acetone for two minutes. A small amount of sodium carbonate $\left(\mathrm{Na}_{2} \mathrm{CO}_{4}\right)$ was also used for checking the degradation of pigments and the sampled tubes were centrifuged for 10 minutes. Whatman number 1 filter paper was used to filter the homogenate mixtures and made up to $25 \mathrm{ml}$ with cold $80 \%$ acetone. Then the centrifuged samples were incubated for 30 minutes at dark. Finally, reading was taken at $645 \mathrm{~nm}$ and $663 \mathrm{~nm}$ with the use of a UV-VIS spectrophotometer and expressed as mg/gfw (Porra et al., 1989).

\section{Calculation}

The formula for computing total chlorophyll, chlorophyll-a, chlorophyll $-b$ and carotenoids are as follows.

Total chlorophyll

$$
\begin{aligned}
& =\left(20.2 \times \mathrm{D}_{645}+8.02\right. \\
& \left.\times \mathrm{D}_{663}\right) \times 0.2
\end{aligned}
$$

Total chlorophyll - a

$$
\begin{aligned}
& =\left(12.7 \times \mathrm{D}_{663}-2.69\right. \\
& \left.\times \mathrm{D}_{645}\right) \times 0.2
\end{aligned}
$$

Total chlorophyll - b

$$
\begin{aligned}
& =\left(22.9 \times \mathrm{D}_{645}-4.68\right. \\
& \left.\times \mathrm{D}_{663}\right) \times 0.2
\end{aligned}
$$

$$
\mathrm{Cc}=4.695 \times \mathrm{D}_{645}-0.268 \mathrm{C}(\mathrm{a}+\mathrm{b})
$$

where, $\mathrm{Cc}=$ concentration of carotenoids in $\mathrm{mg} \mathrm{L}^{-1}, \mathrm{D}_{645}=$ absorbance at $645 \mathrm{~nm}$ wavelength, D663 = absorbance at $663 \mathrm{~nm}$ wavelength, 20.2, 8.02, 12.7, 2.69, 22.9 and $4.68=$ absorbance co-efficient, $0.2=$ dilution factor. The same procedure was followed at 60 DAP and 100 DAP accordingly. 


\section{Statistical Analysis}

The collected data were compiled and tabulated in proper form and subjected to statistical analysis. Data were analysed using the analysis of variance technique with the help of computer package program MSTAT-C and mean differences were adjudged with $1 \%$ probability by Duncan's Multiple Range Test (DMRT).

\section{RESULTS AND DISCUSSION}

\section{Growth Parameters}

Characteristics of Leaves

The genotypes under the study showed wide variation with respect to leaf characters. The shape of leaf blade and leaf vein colour of mature leaves varied remarkably among the nine genotypes. The distinctive characteristics in the shape of leaves were observed. The mature leaves of genotypes JSP 2 and JSP 4 were elliptical in shape, JSP 3, BARI SP 9 and local 2 were in winged shaped leaves. Tri-lobbed butterflyshape was found in local 1, local 3, almost triangle-shaped was found in JSP 1 and heart-shaped was observed in BARI SP 7. There was noticeable variation among the genotypes in the colour of leaf blade and leaf vein
(Figure 1). The colour of leaf blades of mature leaves was found almost green in all varieties, but the deep green colour was found in local 2. The leaf vein colour was also found green and only JSP 1 was purple in colour. Small variation was observed among the genotypes in vein petiole colour. The leaf vein and petiole colour of all genotypes were found green, except JSP 1 which was purple. A wide variation showed in the adjacent point of the leaf blade and petiole colour. The adjacent point of the leaf blade and petiole colour were found green in JSP 2, JSP 3, BARI SP 7, BARI SP 9, local 3, and purple in JSP 1, JSP 4, local 1 and local 2 (Figure 1).

\section{Characteristics of Vine}

Non-significant variation was noticed in vine characters of the genotypes. The vine colour of JSP 2, JSP 3, BARI SP 7, Local 1, Local 2 and Local 3 was green and deep green was observed in BARI SP 9 while JSP 1 vine was in purple (Table 2). Twig colour showed purple only in JSP 3, but all other genotypes showed green colour in twigs. In JSP 1 hair was present in their vine while soft and succulent vine was found in Local 1 and Local 3. Leaf and vine characters are controlled by the genetic makeup of 


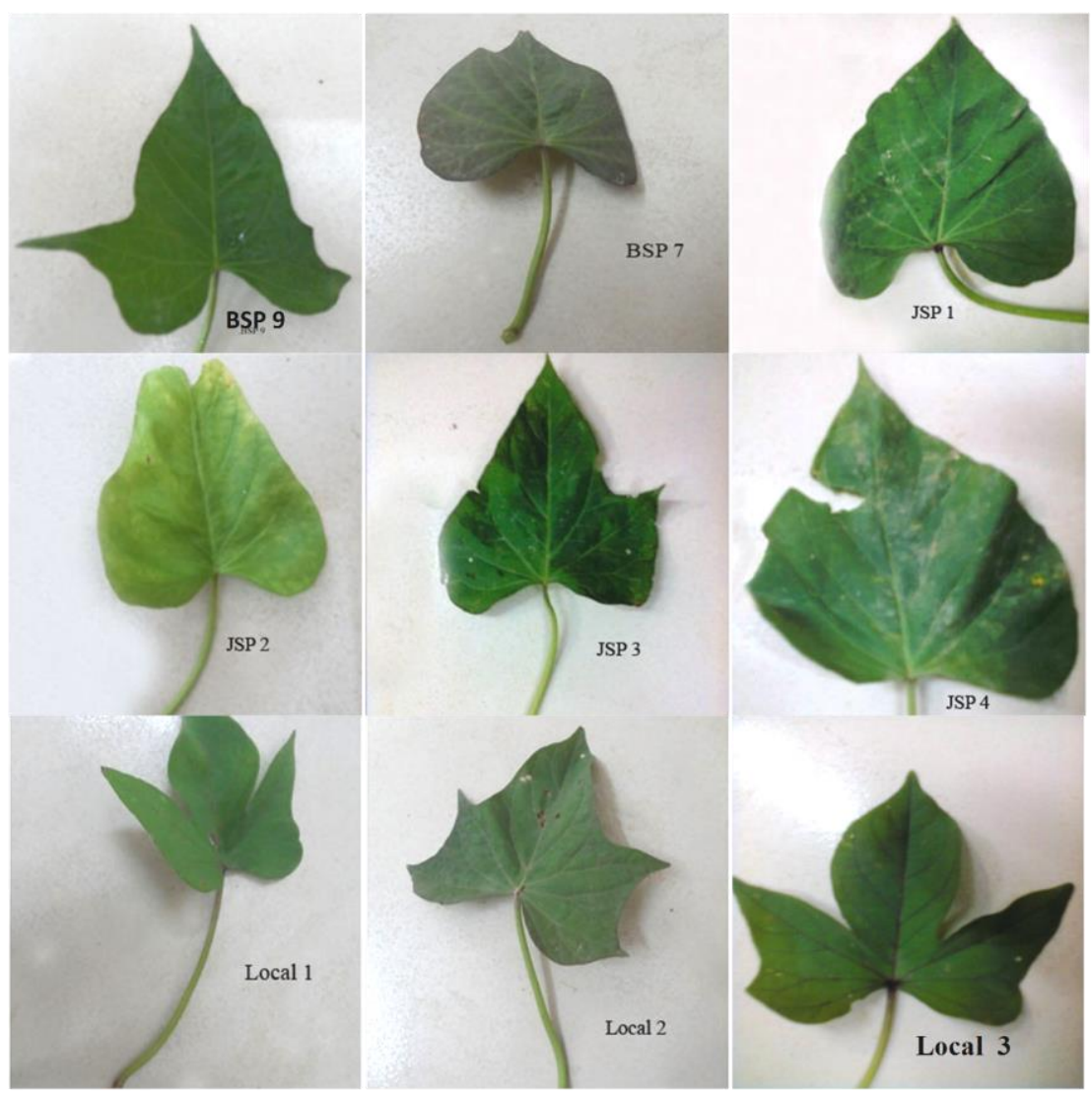

Figure 1. Leaf characteristics of different sweetpotato genotypes

Table 2. Morphological features of vine and storage root of nine sweetpotato genotypes.

\begin{tabular}{|c|c|c|c|c|}
\hline \multirow[t]{2}{*}{ Genotypes } & \multirow[t]{2}{*}{ Vine colour } & \multicolumn{3}{|c|}{ Storage root } \\
\hline & & Shape & Skin colour & Flesh colour \\
\hline JSP 1 & Purple and hairy & Fusiform & $\begin{array}{l}\text { White to light } \\
\text { yellowish }\end{array}$ & Light yellowish, lattice absent \\
\hline JSP 2 & Green & Fusiform & Yellow & Yellow, lattice absent \\
\hline JSP 3 & Light purple or green & Globose & Deep orange & $\begin{array}{l}\text { Deep orange, white lattice } \\
\text { present }\end{array}$ \\
\hline JSP 4 & Green, succulent & Fusiform & Light yellow & Light yellow, lattice absent \\
\hline BSP 7 & Green & Fusiform & Yellow & $\begin{array}{l}\text { Deep yellow, white lattice } \\
\text { present }\end{array}$ \\
\hline BSP 9 & Vine is deep green & Elliptical & Brownish & Brownish, white lattice present \\
\hline Local 1 & Green, succulent & Fusiform & Light yellow & White, lattice absent \\
\hline Local 2 & Green, elongated & Fusiform & Red & Whitish, lattice absent \\
\hline Local 3 & $\begin{array}{l}\text { Green, soft and } \\
\text { succulent }\end{array}$ & Fusiform & Light yellow & Light yellow, lattice absent \\
\hline
\end{tabular}

JSP: Japanese Sweetpotato, BSP : BARI Sweetpotato. 
the genotype and it is quite obvious that these are different from one genotype to another. The leaf and vine characters of different sweetpotato genotypes of this study were close to the findings of Rahman et al (2015).

\section{Characteristics of Storage Roots}

Storage roots of sweetpotato genotypes showed wide variation in respect of shape (Figure 2). The shape of the storage root was fusiform or globose or elliptical. Among the nine sweetpotato genotypes, JSP 1, JSP 2, JSP 4, BARI SP 7, Local 1, Local 2 and Local 1 were fusiform, JSP 3 was globose and the BSP 9 was elliptical. With respect to skin and flesh colour, storage roots of different genotypes of sweetpotato showed wide variation (Table 2). The skin was light yellow in JSP 1, JSP 4, Local 1 and Local 3, yellow in JSP 2 and BARI SP 7, deep orange in JSP 3, brown in BARI SP 9 and red in Local 2. Flesh colour of JSP 1, JSP 2, JSP 4 and Local 3 was yellow while BARI SP 7, Local 1 and Local 2 showed white, JSP 3 was deep orange and BARI SP 9 was brown. White lattice was found in JSP 3, BARI SP 7 and BARI SP 9. Storage root characters are controlled by genetic makeup of a variety and it is obvious that these are different from one genotype to another. Due to presence of the different types of pigments, sweetpotatoes show various colours of the tuber skin. Storage root characters particularly storage root shape, size, skin colour and flesh colour were in partial agreement with the results of Hossian and Siddique (2008). Different skin colours of sweet potato tuber have been reported as white, yellow, red, pink, orange, cream and dark purple by Hayati et al. (2020).

\section{Vine Length}

All the genotypes of sweetpotato showed significant variation in vine length (Figure 3). Results revealed that vine length increased until 90 DAS followed by a rapid increase till maturity (150 DAS) parallel to the increase in rainfall pattern. The genotype, local 3 showed the longest $(158.4 \mathrm{~cm})$ vine at growth stage. The shortest $(96.3 \mathrm{~cm})$ vine was recorded in JSP 2 which was statistically similar to JSP $3(96.63 \mathrm{~cm})$, JSP $1(103.8 \mathrm{~cm})$, local $1(99.50 \mathrm{~cm})$ and Local $2(100.4 \mathrm{~cm})$. Differences in vine length were observed due to the genetic makeup present in the genotypes that might attribute to the tolerance for the acidic soil environment. The present findings are compatible with the findings of Rahman et al. (2015) who stated that wide spacing increased vine growth but reduced tuber number per plant, while 


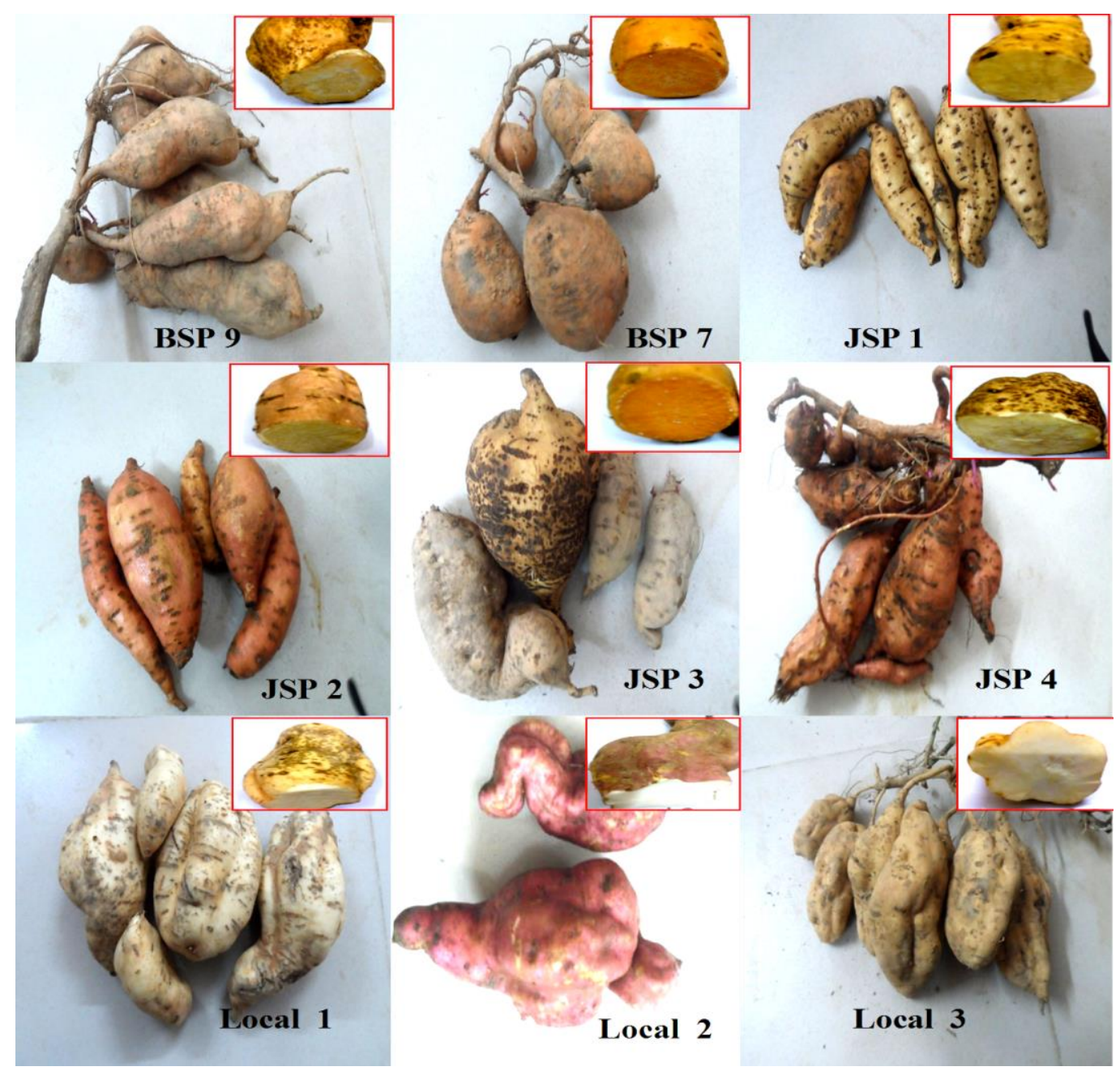

Figure 2. Skin and flesh colour of storage root of different sweetpotato genotypes tested in this study

narrow spacing increased tuber yield. Kareem (2013) reported that vine length ranges from 110-140 $\mathrm{cm}$ gave the best yield of sweetpotato and similar observation was made in the present study.

Leaf Area per Leaf at Different Days of Planting
There was a noticeable variation observed in the leaf area on different days after planting (Table 3). At 120 DAP, the highest leaf area was found in JSP $4\left(80.77 \mathrm{~cm}^{2}\right)$ which was statistically similar to JSP $1\left(78.50 \mathrm{~cm}^{2}\right)$ and the lowest leaf area was recorded in Local 1 $\left(49.37 \mathrm{~cm}^{2}\right)$ that was statistically similar to BARI SP $7\left(49.77 \mathrm{~cm}^{2}\right)$. Kathabwalika et al. (2013) conducted a similar type of experiment in the three regions of 


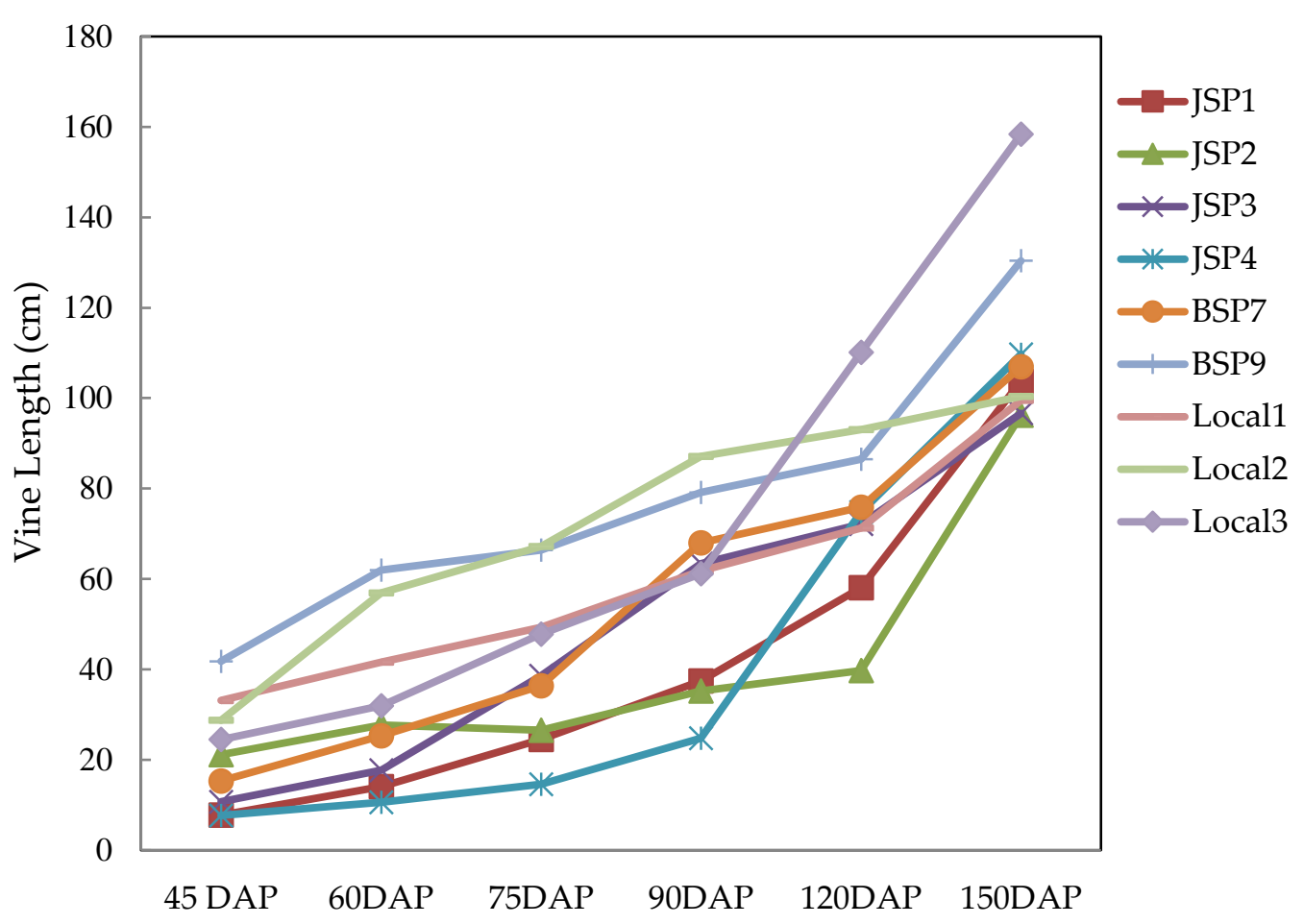

Figure 3. Vine length of sweetpotato genotypes at different days after planting in acid soil

Table 3. Leaf Area per leaf at different days of planting of selected sweetpotato genotypes.

\begin{tabular}{|c|c|c|c|c|c|}
\hline \multirow[t]{2}{*}{ Genotypes } & \multicolumn{3}{|c|}{$\begin{array}{l}\text { Leaf area }\left(\mathrm{cm}^{2}\right) \text { per leaf at different } \\
\text { days of planting }\end{array}$} & \multirow{2}{*}{$\begin{array}{l}\begin{array}{l}\text { Leaf area } \\
\text { index (LAI) }\end{array} \\
150 \text { DAP }\end{array}$} & \multirow{2}{*}{$\begin{array}{l}\text { Number of } \\
\text { leaves at } \\
\text { maturity }\end{array}$} \\
\hline & 75 DAP & 90 DAP & 120 DAP & & \\
\hline JSP 1 & $53.70^{\mathrm{ab}}$ & $66.80^{a}$ & $78.50^{a}$ & $13.40^{\mathrm{a}}$ & $193.0^{c}$ \\
\hline JSP 2 & $51.00^{\mathrm{ab}}$ & $53.47^{\mathrm{bc}}$ & $64.20^{\mathrm{b}}$ & $3.60^{\mathrm{d}}$ & $75.0^{\mathrm{f}}$ \\
\hline JSP 3 & $42.33^{\mathrm{bcd}}$ & $50.30^{\mathrm{cd}}$ & $62.53^{\mathrm{b}}$ & $8.34^{\mathrm{b}}$ & $221.0^{\mathrm{b}}$ \\
\hline JSP 4 & $60.73^{a}$ & $63.57^{\mathrm{ab}}$ & $80.77^{a}$ & $6.14^{\mathrm{c}}$ & $97.0^{\mathrm{ef}}$ \\
\hline BSP 7 & $38.20^{\text {cde }}$ & $40.03^{\text {def }}$ & $49.77^{b}$ & $2.73^{\mathrm{d}}$ & $95.0^{\mathrm{ef}}$ \\
\hline BSP 9 & $46.13^{\mathrm{bc}}$ & $49.53^{\text {cde }}$ & $61.97^{b}$ & $8.20^{b}$ & $246.0^{\mathrm{a}}$ \\
\hline Local 1 & $32.40^{\text {de }}$ & $37.13^{\mathrm{ef}}$ & $49.37^{b}$ & $8.71^{b}$ & $218.0^{\mathrm{b}}$ \\
\hline Local 2 & $52.23^{\mathrm{ab}}$ & $55.37^{\mathrm{abc}}$ & $64.13^{b}$ & $5.72^{c}$ & $147.0^{\mathrm{d}}$ \\
\hline Local 3 & $28.87^{e}$ & $32.80^{\mathrm{f}}$ & $52.70^{\mathrm{b}}$ & $3.26^{\mathrm{d}}$ & $102.0^{\mathrm{e}}$ \\
\hline CV $(\%)$ & 10.36 & 10.28 & 9.53 & 6.37 & 6.37 \\
\hline
\end{tabular}

Values having the same letter (s) in a column do not differ significantly at $P<0.1$ 
Malawi having alfisol and lithosol soil types and found that genotype LU06/0428 produced the highest leaf area of $130.9 \mathrm{~cm}^{2}$ followed by BV/009 with $97.7 \mathrm{~cm}^{2}$.

\section{Leaf Area Index at Harvest}

The leaf area index also showed a noticeable variation at 150 DAP shown in (Table 3). At $150 \mathrm{DAP}$, the highest leaf area index was found in JSP 1 (13.40) and the lowest leaf area was recorded in BARI SP 7 (2.73) which was statistically similar to Local 3 (3.26) and JSP 2 (3.60). Hossain et al. (2018) reported that leaf area increased gradually up to $120 \mathrm{DAP}$.

Chlorophyll and Carotenoid Content in Leaves

Chlorophyll-a content of all genotypes increased up to 60 days of planting and then it decreased except for genotype BSP 9, where it increased up to 90 days of planting (Table 4 ).

Table 4. Chlorophyll-a Chlorophyll-b and Carotenoids of the leaves of sweetpotato genotypes at different days of planting.

\begin{tabular}{llllllllll}
\hline $\begin{array}{l}\text { Genoty } \\
\text { pes }\end{array}$ & \multicolumn{2}{l}{$\begin{array}{l}\text { Chlorophyll content at 30 } \\
\text { DAP mg/gfw }\end{array}$} & \multicolumn{3}{l}{$\begin{array}{l}\text { Chlorophyll content at 60 } \\
\text { DAP mg/gfw }\end{array}$} & \multicolumn{3}{c}{$\begin{array}{l}\text { Chlorophyll content at 90 } \\
\text { DAP mg/gfw }\end{array}$} \\
\cline { 2 - 10 } & $\begin{array}{l}\text { Chloro } \\
\text { phyll-a }\end{array}$ & $\begin{array}{l}\text { Chlorop } \\
\text { hyll-b }\end{array}$ & $\begin{array}{l}\text { Carote } \\
\text { noids }\end{array}$ & $\begin{array}{l}\text { Chloro } \\
\text { phyll-a }\end{array}$ & $\begin{array}{l}\text { Chloro } \\
\text { phyll-b }\end{array}$ & $\begin{array}{l}\text { Caroten } \\
\text { oids }\end{array}$ & $\begin{array}{l}\text { Chloro } \\
\text { phyll-a }\end{array}$ & $\begin{array}{l}\text { Chloro } \\
\text { phyll-b }\end{array}$ & $\begin{array}{l}\text { Carote } \\
\text { noids }\end{array}$ \\
\hline JSP 1 & 0.029 & $0.125^{\mathrm{be}}$ & $2.474^{\mathrm{f}}$ & 0.069 & 0.019 & $3.573^{\mathrm{f}}$ & 0.038 & 0.016 & $3.963^{\mathrm{e}}$ \\
JSP 2 & 0.040 & $0.165^{\mathrm{b}}$ & $3.076^{\mathrm{c}}$ & 0.090 & 0.030 & $3.714^{\mathrm{e}}$ & 0.066 & 0.032 & $4.713^{\mathrm{c}}$ \\
JSP 3 & 0.046 & $0.191^{\mathrm{a}}$ & $3.620^{\mathrm{a}}$ & 0.098 & 0.034 & $3.808^{\mathrm{d}}$ & 0.093 & 0.045 & $5.392^{\mathrm{b}}$ \\
JSP 4 & 0.029 & $0.126^{\mathrm{de}}$ & $2.520^{\mathrm{f}}$ & 0.086 & 0.037 & $4.711^{\mathrm{a}}$ & 0.085 & 0.031 & $4.660^{\mathrm{c}}$ \\
BSP 7 & 0.032 & $0.129^{\mathrm{d}}$ & $2.614^{\mathrm{e}}$ & 0.061 & 0.024 & $3.214^{\mathrm{g}}$ & 0.057 & 0.033 & $4.088^{\mathrm{d}}$ \\
BSP 9 & 0.025 & $0.102^{\mathrm{e}}$ & $2.363^{\mathrm{g}}$ & 0.067 & 0.026 & $4.242^{\mathrm{b}}$ & 0.076 & 0.050 & $5.493^{\mathrm{a}}$ \\
Local 1 & 0.033 & $0.137^{\mathrm{cd}}$ & $2.918^{\mathrm{d}}$ & 0.089 & 0.026 & $4.070^{\mathrm{c}}$ & 0.037 & 0.015 & $3.340_{\mathrm{g}}$ \\
Local 2 & 0.036 & $0.155^{\mathrm{bc}}$ & $3.197^{\mathrm{b}}$ & 0.048 & 0.031 & $3.191 \mathrm{~g}$ & 0.021 & 0.034 & $3.298^{\mathrm{h}}$ \\
Local 3 & 0.029 & $0.116^{\mathrm{de}}$ & $3.233^{\mathrm{b}}$ & 0.090 & 0.025 & $4.198^{\mathrm{b}}$ & 0.037 & 0.014 & $3.455^{\mathrm{f}}$ \\
CV (\%) & 3.05 & 0.360 & 0.07 & 1.29 & 2.53 & 0.06 & 6.41 & 5.78 & 0.12 \\
${ }^{*}$ LS & NS & 0.01 & 0.01 & NS & NS & 0.01 & NS & NS & 0.01 \\
\hline
\end{tabular}

${ }^{*}$ LS = Level of significant, Values having the same letter (s) in a column do not differ significantly at $1 \%$ level of significance 
The maximum chlorophyll-b was found at 30 days after planting in all of the genotypes and the minimum was found at 90 DAP except for genotypes BSP 7, BSP 9 and Local 2. Carotenoids contents of all genotypes increased up to 90 DAP except Local 1 and Local 3 genotypes. The content of chlorophyll$a$, chlorophyll-b and ratio of chlorophyll-a to chlorophyll-b differed among the cultivars (Rashid et al., 2002).

\section{Number of Branches per Plant}

The number of branches per plant reflects the significant effect on plant growth (Figure 4). It is an important morphological parameter contributing to yield because it increases the number of leaves and increases photosynthetic product. Results showed that the number of primary branches per plant increased gradually from 45 DAP until maturity in all growth stages of sweetpotato genotypes. The highest number of primary branches was recorded in Local 1 (6.03) which was statistically similar to JSP 1 (5.70), JSP 3 (5.63), Local 3 (5.63), BARI SP 9 (5.53) and the lowest number of branches in BARI SP 7 (4.27) in 150 days. The number of branches might differ significantly due to variety, agronomic practices and their interactions. The findings of the present experiment are similar to the findings of Shen et al. (2015). Martha (2014) noticed that both the main effects of variety and planting density significantly influenced the number of branches per plant which could be due to the genetic capacity of up taking nutrients from the soil.

\section{Dry Weight of Leaves per Plant}

There were noticeable wide variations among the genotypes in respect of the dry weight of leaves (Table 5). The highest dry weight was found in Local 2 (30.87 g) and the lowest was found in BARI SP 7 (5.8 g) (Table 5). Delowar and Hakim (2014) mentioned that the dry weight of leaves in genotypes is affected by soil acidity.

Dry Weight of Vine, Absorbing Roots and Storage Roots per Plant

Variations were observed among different sweetpotato genotypes in respect of the dry weight of vines, absorbing roots and storage roots (Table 5). The highest dry weight of vine was found in Local 2 (27.20 g) which was statistically similar to BARI SP 9 (27.03 g) and the lowest was found in BARI SP 7 (11.53 g). The maximum dry matter of absorbing roots was 


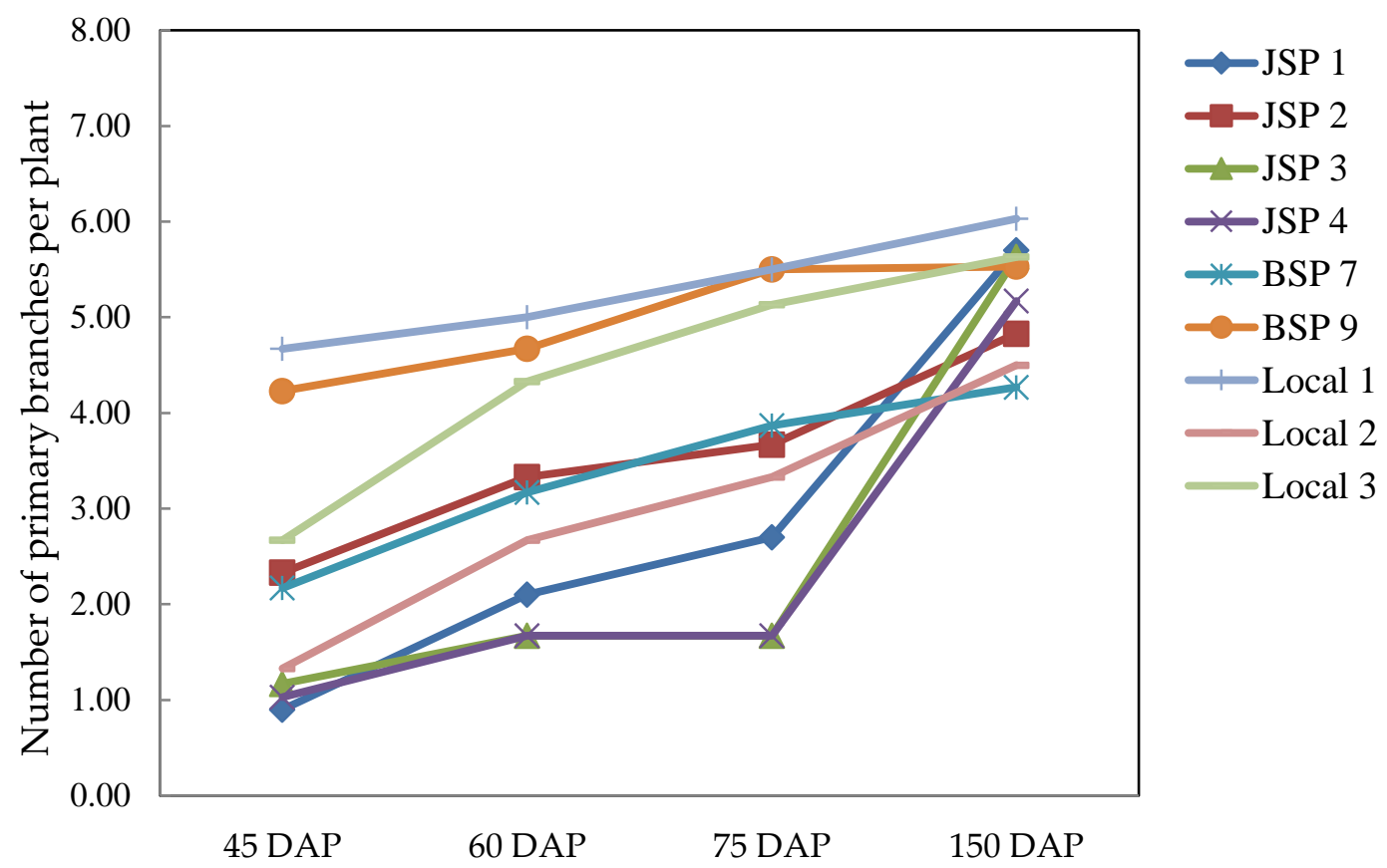

Figure 4. Number of branches per plant at different days after planting in acid soil

Table 5. Dry weight (g) of leaf, vine, absorbing root and storage root, total fresh and dry weight (g) of plant and \% moisture on storage root per plant of selected sweetpotato genotypes.

\begin{tabular}{|c|c|c|c|c|c|c|c|}
\hline $\begin{array}{l}\text { Genotyp } \\
\text { es }\end{array}$ & $\begin{array}{l}\text { Leaf dry } \\
\text { weight } \\
\text { plant }^{-1}(g)\end{array}$ & $\begin{array}{l}\text { Vine dry } \\
\text { weight } \\
\text { plant }^{-1}(g)\end{array}$ & $\begin{array}{l}\text { Absorbing } \\
\text { root dry } \\
\text { weight } \\
\text { plant }^{-1}(g)\end{array}$ & $\begin{array}{l}\text { Storage } \\
\text { root dry } \\
\text { weight } \\
\text { plant }^{-1}(g)\end{array}$ & $\begin{array}{l}\text { Total fresh } \\
\text { weight } \\
\text { plant }^{-1}(g)\end{array}$ & $\begin{array}{l}\text { Total dry } \\
\text { weight } \\
\text { plant }^{-1}(g)\end{array}$ & $\begin{array}{l}\text { \% Moisture } \\
\text { on storage } \\
\text { root plant }{ }^{-1}\end{array}$ \\
\hline JSP 1 & $19.33^{\mathrm{cd}}$ & $26.23^{a}$ & $0.6^{\mathrm{a}}$ & $104.5^{\mathrm{h}}$ & $550.3^{d}$ & 152.9 e & $42.9^{a}$ \\
\hline JSP 2 & $18.47^{\mathrm{d}}$ & $20.57^{d}$ & $0.2^{b}$ & $146.8^{\mathrm{fg}}$ & $620.9^{d}$ & $184.0^{\mathrm{d}}$ & $40.6^{\text {bcd }}$ \\
\hline JSP 3 & $8.9^{e}$ & $14.30^{\mathrm{cd}}$ & $0.3^{b}$ & $163.0^{\text {ef }}$ & $577.1^{\mathrm{d}}$ & $186.6^{\mathrm{d}}$ & $42.4^{\mathrm{ab}}$ \\
\hline JSP 4 & $21.73^{b c}$ & $25.73^{a}$ & $0.3^{\mathrm{b}}$ & $119.3^{\mathrm{gh}}$ & $650.1^{\mathrm{d}}$ & $167.1^{\text {de }}$ & $40.0^{\mathrm{cd}}$ \\
\hline BSP 7 & $5.8^{\mathrm{e}}$ & $11.53^{\mathrm{d}}$ & $0.1^{\mathrm{b}}$ & $177.6^{\mathrm{de}}$ & $569.0^{d}$ & $195.1^{\mathrm{d}}$ & 41.9abc \\
\hline BSP 9 & $25.0^{\mathrm{b}}$ & $27.03^{a}$ & $0.2^{\mathrm{b}}$ & $204.0^{\mathrm{cd}}$ & $1074.0^{\mathrm{ab}}$ & $256.3^{c}$ & $32.0^{\mathrm{f}}$ \\
\hline Local 1 & $23.20^{b c}$ & $15.27^{c}$ & $0.1^{\mathrm{b}}$ & $323.8^{a}$ & $1132.0^{\mathrm{a}}$ & $362.4^{a}$ & $39.2^{\mathrm{d}}$ \\
\hline Local 2 & $30.87^{a}$ & $27.20^{\mathrm{a}}$ & $0.5^{\mathrm{a}}$ & $239.8^{\mathrm{b}}$ & $985.1^{\mathrm{bc}}$ & $298.4^{\mathrm{b}}$ & $39.9^{\mathrm{cd}}$ \\
\hline Local 3 & $23.23^{b c}$ & $15.50^{c}$ & $0.7^{a}$ & $226.3^{b c}$ & $961.2^{c}$ & $265.6^{c}$ & $34.20^{\mathrm{e}}$ \\
\hline CV (\%) & 7.59 & 6.71 & 20.41 & 4.94 & 5.14 & 5.14 & 2.08 \\
\hline
\end{tabular}

Values having the same letter (s) in a column do not differ significantly at $P<0.1$ 
found in the genotypes Local 3 (0.7 g) and the minimum dry weight was found in BARI SP $7(0.1 \mathrm{~g})$ and Local 1 $(0.1 \mathrm{~g})$. The weight of storage roots per plant is the most important yield contributing character. The maximum dry weight of storage roots was found in Local $1(323.8 \mathrm{~g})$ and minimum was found in JSP 1 (104.5 g). Delowar and Hakim (2014) reported that the dry weight of storage roots depended on the varietal performance of the particular soil.

\section{Total Fresh and Dry Weight per Plant}

Genotypes of sweetpotato showed significant variation in total fresh weight per plant (Table 5). The maximum total fresh weight recorded in the genotypes of Local 1 was $1132 \mathrm{~g}$ and the minimum total fresh weight was found in JSP 1 (550.3 g) which was statistically similar to BARI SP 7 (569.0 g) and JSP 3 (577.1 g). Onunka et al. (2012) showed similar result where the highest fresh weight per plant was found in the genotype Kamala sinduri (1301 g) and the lowest was found in the genotype Doulatpuri (420 g). Moreover, there was noticeable variation among the nine genotypes in total dry matter content which is shown in Table 5. The highest total dry matter was found in Local 1 (362.4 g) and the lowest total dry matter was found in JSP 1 (152.9 g). Hossain et al. (2018)) reported that the total biomass yield was increased linearly upto 150 days from the date of planting in all cultivars in which the total dry matter yield varied from 131.34 to 313.54 g per plant at harvest.

The Moisture Content of Storage Root per Plant

There was a little variation among the genotypes in the percent of moisture content of storage roots. The highest moisture percentage on storage roots per plant ${ }^{-}$was found in genotype JSP 1 $(42.9 \%)$ and the lowest moisture percentage on storage root $(32.0 \%)$ was found in genotype BARI SP 9. The higher moisture content of storage roots per plant was also reported in different local and exotic sweetpotato cultivars which were ranged from 62.5 to $74.85 \%$ (Hossain et al., 2018).

\section{Yield Parameters}

Number of Storage Roots per Plant

The number of storage roots per plant was significantly varied and shown in Table 6. The maximum number of storage roots was found in JSP 2 (7.60) and the lowest number was recorded in JSP 4 (3.37). Due to genetic variability with acid tolerance, the number of 
storage roots varied among different sweetpotato genotypes. Rahman et al (2015) reported that according to their study, the number of storage roots per plant varied from 2 to 7.33 which is in agreement with our findings.

\section{Length and Diameter of Storage Roots}

The maximum length $(12.73 \mathrm{~cm})$ of storage roots was observed in the genotypes BARI SP 9 which was statically similar to Local $2(12.07 \mathrm{~cm})$ and Local $1(12.03 \mathrm{~cm})$ (Table 6). The lowest length of storage roots was observed in the genotype JSP 2 (8.70 $\mathrm{cm})$. It is clearly indicated that the highest storage root length producing genotypes of sweetpotato in acidic soil influences the higher production of yield. The diameter of storage roots per plant was significantly different ranging from 15.50 to 9.37. The maximum diameter (15.50) was recorded in the genotypes Local 3 followed by Local 1 (14.63) and Local 2 (14.27). The lowest mean diameter of storage roots was observed in the genotype of JSP 2 (9.37). The diameter of storage roots differs from various genotypes due to variations in growth habits as well as their capacity to tolerate acidic soil (Hossain et al., 2018).

Yield of Storage Roots
The data on yield of storage roots of nine sweetpotato genotypes were measured and presented in Table 6 . Storage roots yield ( $\left.t \mathrm{ha}^{-1}\right)$ of sweetpotato genotypes had statistically significant variation. The highest storage roots yield $\left(27.05 \mathrm{t} \mathrm{ha}^{-1}\right)$ was produced by the genotype Local 1 . The lowest yield (5.43 $\mathrm{tha}^{-1}$ ) was found from the genotype JSP 4 which was statistically similar to the genotype JSP $1\left(5.67 \mathrm{t} \mathrm{ha}^{-1}\right)$. The results of our study are close to the findings of Kareem (2013) where the yield of storage roots of different genotypes of sweetpotato ranged from 5.43 to $10.90 \mathrm{t} \mathrm{ha}^{-1}$. We also observed the correlation of higher tuber fresh weight with higher tuber yield that was reported by Hayati et al. (2020) and Hossain et al. (2018).

\section{CONCLUSION}

Based on the findings of the study, the genotypes Local 1 showed the best performance in yield and growth parameters whereas genotypes JSP 2 and JSP 3 which were orange-fleshed had higher beta carotene content. As future work nutritional quality of the genotypes such as Local 1, JSP 2 and JSP 3 need to be undertaken for improving purpose. 
Table 6. Yield contributing characters of selected sweetpotato genotypes

\begin{tabular}{|c|c|c|c|c|}
\hline Genotypes & $\begin{array}{l}\text { No. of } \\
\text { storage } \\
\text { root plant }{ }^{-1}\end{array}$ & $\begin{array}{l}\text { Length of } \\
\text { storage root } \\
\text { plant }^{-1}(\mathrm{~cm})\end{array}$ & $\begin{array}{l}\text { Diameter of } \\
\text { storage root } \\
\text { plant }^{-1}(\mathrm{~cm})\end{array}$ & Yield (t/ha) \\
\hline JSP 1 & $3.17^{\mathrm{d}}$ & $10.13^{\mathrm{bcd}}$ & $10.93^{\mathrm{cd}}$ & $5.67^{f}$ \\
\hline JSP 2 & $7.60^{\mathrm{a}}$ & $8.70^{\mathrm{d}}$ & $9.37^{\mathrm{d}}$ & $13.66^{\mathrm{d}}$ \\
\hline JSP 3 & $5.07^{b c}$ & $9.13^{\mathrm{d}}$ & $11.17^{\mathrm{cd}}$ & $9.61^{e}$ \\
\hline JSP 4 & $3.37^{\mathrm{d}}$ & $9.50^{\mathrm{cd}}$ & $14.27^{\mathrm{a}}$ & $5.43^{f}$ \\
\hline BSP 7 & $4.23^{\mathrm{cd}}$ & $8.93^{\mathrm{d}}$ & $13.83^{\mathrm{ab}}$ & $14.86^{\mathrm{cd}}$ \\
\hline BSP 9 & $6.10^{\mathrm{b}}$ & $12.73 a$ & $12.20^{\mathrm{bc}}$ & $18.10^{\mathrm{b}}$ \\
\hline Local 1 & $4.67^{\mathrm{bcd}}$ & $12.03^{\mathrm{ab}}$ & $14.63^{\mathrm{a}}$ & $27.05^{\mathrm{a}}$ \\
\hline Local 2 & $4.33^{\mathrm{cd}}$ & $12.07^{\mathrm{ab}}$ & $11.50^{c}$ & $13.66^{\mathrm{d}}$ \\
\hline Local 3 & $3.77^{\mathrm{cd}}$ & $11.37^{\mathrm{abc}}$ & $15.50^{\mathrm{a}}$ & $15.50^{c}$ \\
\hline CV (\%) & 13.35 & 7.51 & 6.12 & 4.04 \\
\hline
\end{tabular}

Values having same letter (s) in a column do not differ significantly at $P<0.1$

\section{REFERENCES}

Chandrasekara, A. and Josheph kumar, T. (2016). Roots and tuber crops as functional foods: A review on phytochemical constituents and their potential health benefits. International Journal of Food Science, 2016, Article ID 3631647. DOI: org/10.1155/2016/3631647.

Delowar, H. K. M. and Hakim, M.A. (2014). Effect of salinity levels on the morpho-physiological characteristics and yield attributes of sweetpotato genotypes. International Journal of Science and Research, 10: 929- 934.

Essilfie E. M., Blay, E. T. and Norman, J.C. (2015). Yield and storability of sweetpotato (Ipomoea batatas (L.) Lam) as influenced by chicken manure and inorganic fertilizer. PhD Thesis. Department of Crop Science, University of Ghana. 292p. FAOSTAT (2019). Food and Agriculture Data; Food and Agriculture Organization of the United Nations: Rome, Italy, http://www.fao.org/faostat/en/\#dat $\mathrm{a} / \mathrm{QC}$ (accessed on $10^{\text {th }}$ August 2021). Hayati, M., Sabaruddin, Efendi and Anhar, A. (2020). Morphological characteristics and yields of several sweet potato (Ipomoea batatas L.) tubers. Earth and Environmental Sciences, 425, 012055.

Hossain, M. M. and Siddique, M. A. (2008). Sweetpotato: production, use 
and improvement (in Bengali). Mrs. Hena Siddique, E-25/3, Bangladesh Agricultural University Campus, Mymensingh. P. 112.

Hossain, M. A.S., Islam, A.F.M.S., Miah, M.N.H. and Khan, M.M.H. (2018). Evaluation on growth and yield of sweetpotato genotypes in Ramgarh soil series of low hills in Sylhet. Journal of Sylhet Agricultural University, 5(1):19 - 30.

Kareem, I. (2013). Fertilizer treatment effects on yield and quality parameters of sweet potato (Ipomoea batatas). Research Journal of Chemical and Environmental Sciences, 1(3): 4049.

Kathabwalika, D. M., Chilembwe, E. H. C., Mwale, V. M., Kambewa, D. and Njoloma, J. P. (2013). Plant growth and yield stability of orange fleshed sweetpotato (Ipomoea batatas) genotypes in three agro-ecological zones of Malawi. International Research Journal of Agricultural and Soil Sciences, 3(11): 383-392.

Laurie, S. M. and Niederwieser, J. G. (2004). The sweetpotato plant. In Niederwieser, J.G. (ed.). Guide to Sweetpotato Production in South Africa. Agricultural Research Council1: 7-14. South Africa, Pretoria.

Laurie, S. M. and Heerden, S. M. Van. (2012). Consumer acceptability of four products made from betacarotene-rich sweet potato. African Journal of Food Sciences, 6: 96-103.
Mahmud, A. A., Hassan, M. M., Alam, M. J., Molla, M. S. H., Ali, M. A., Mohanta, H. C., Alam, M. S., Islam, M. A., Talukder, M. A. H., Ferdous, M. Z., Amin, M. R., Hossain, M. F., Anwar, M. M., Islam, M. S., Dessoky, E. S. and Hossain (2021). Farmers' preference, yield, and GGE-biplot analysis-based evaluation of four sweet potato (Ipomoea batatas L.) varieties grown in multiple environments. Sustainability, 13, 3730. DOI: org/10.3390/su13073730

Martha, M. (2014). Sweetpotato (Ipomoea batatas (L.)Lam) growth and yield as affected by planting density and cultivar in Wolaita Soddo, Souther Ethiopia. M.Sc. thesis, Haramaya University.

Motsa, N. M., Modi, A. T. and Mabhaudhi, T. (2015). Sweet potato (Ipomoea batatas L.) as a drought tolerant and food security crop. Journal of South African Sciences, 11(1):11-12.

Namanda, S. (2012). Current and potential systems for maintaining sweetpotato planting materials in areas with prolonged dry seasons: a biological, social and economic framework. PhD Dissertation, UK: Natural Resources Institute, University of Greenwich.

Nazrul, M. I. (2018). On-farm evaluation of orange fleshed sweet potato varieties under acidic soil of north-east region in Bangladesh. 
Bangladesh Agronomy Journal, 21(2): 59-65.

Onunka, N. A., Chukwu, L. I., Mbanasor, E. O. and Ebeniro, C. N. (2012). Effect of organic and inorganic manures and time of application on soil properties and yield of sweetpotato in a tropical ultisol. Journal of Agriculture and Social Research, 12: 183-194.

Porra, R. J., Thompson, W. A., and Kriedemann, P. E. (1989). Determination of accurate extraction and simultaneously equation for assaying chlorophyll a and $b$ extracted with different solvents: verification of the concentration of chlorophyll standards by atomic absorption spectroscopy. Biochemistry Biophys Acta, 975: 384-394.

Rahman, H., Islam, A. F. M. S., Maleque, M. A. and Tabassum, R. (2015). Morpho-physiological evaluation of sweet potato (Ipomoea batatas L.) genotypes in acidic soil. Asian Journal of Crop Science, 7(4): 267-276.

Rashid, M. M., Mazumdar, A. A. and Molla, S. (2002). Performance of exotic germplasm of sweetpotato in Bangladesh. Proceedings of the $1^{\text {st }}$ International Conference on Sweetpotato, Food and Health for Future, Lima, Peru, 26-29 July, 2001, pp. 291-295.

Rosero, A., Sierra, C. and Pastrana et al. (2020). Genotypic and environmental factors influence the proximate composition and quality attributes of sweetpotato (Ipomoea batatas L.). Agriculture and Food Security, 9:14.

Shen, S., Xu, G., Clements, D. R., Jin, G., Chen, A., Zhang, F. and KatoNoguchi, H. (2015). Suppression of the invasive plant mile-a-minute (Mikania micrantha) by local crop sweet potato (Ipomoea batatas) by means of higher growth rate and competition for soil nutrients. BMC Ecology, 15. DOI: 10.1186/s12898014-0033-5.

Vargas, P. F., Godoy, D. RZ., Almeida, L. C. F. and Castoldi, R. (2017). Agronomic characterization of sweet potato accessions. Comunicata Scientiae, 8: 116-158.

Verma, V. S., Singh, K. P., Singh, N. K., Singh, J. R. P and Verma, S. P. (1994). Rajendra Shakarkand and Rajendra Shakarkand 43: Two high Yielding elections of sweet potato. Journal of Root Crops, 20: 15-19.

Watson, D. J. (1947). Comparative physiological studies in the growth of field crops. I. Variation in net assimilation rate and leaf area between species and varieties, and within and between years. Annals of Botany, 11: 41-76. 